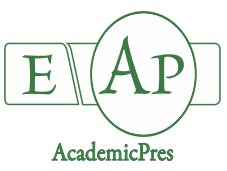

Cong R et al. (2021)

Notulae Botanicae Horti Agrobotanici Cluj-Napoca

Volume 49, Issue 3, Article number 12389

DOI: $10.15835 /$ nbha49312389

Research Article

\title{
Above-ground carbon storage in Pinus pumila along an alpine altitude in Khingan Mountains, Inner Mongolia of China
}

\author{
Rizheng CONG ${ }^{1,2,3 *}$, Hongying $\mathrm{YU}^{1}$, Xiaona $\mathrm{PEI}^{1}$, Fangyuan $\mathrm{SHEN}^{1}$ \\ ${ }^{1}$ Harbin Institute of Forestry Machinery, State Forestry and Grassland Administration, Harbin City, Heilongiiang Province, 150086, \\ China;846235592@qq.com;37748817@qq.com;shuke9197@126.com \\ ${ }^{2}$ State Key Laboratory of Forest Tree Genetics and Breeding, Northeast Forestry University, Harbin City, Heilongiiang Province, \\ 150040,China; congrz@126.com \\ ${ }^{3}$ Fuyuan National Key Field Observation and Research Station for Forest Ecosystem in Heilongiiang, Fuyuan City, Heilongiang \\ Province, 156500,China; congrz@126.com
}

\begin{abstract}
The carbon (C) cycle in alpine ecosystems is sensitive to climate change, but information about the $\mathrm{C}$ storage in its undergrowth is scarce. In October 2017, a total of 6231 Pinus pumila (Pall.) Regel trees were investigated for above-ground growth and density in 60 sub-plots $(10 \times 10 \mathrm{~m})$ from 12 stands $(50 \times 50 \mathrm{~m})$ along the altitudinal gradient (800-1500 m a.s.l.) in Great Khingan Mountains, Inner Mongolia, Northeast China. Sites were characterized by different crown densities (CDs) from $20 \%$ to $90 \%$. Height and root-collar diameter (RCD) were higher in stands with CDs of $40-70 \%$ than CDs of $20-30 \%$. Stem density (SD) and crown area (CA) had a positive correlation with altitude and CD. Equations from local shrub models were used to adapt the allometric growth models for estimation. There were variations in estimated above-ground $\mathrm{C}$ density depending on the model and the involvement of the canopy area. Above-ground $\mathrm{C}$ storage in $P$. pumila individuals ranged from $0.05-2.46 \mathrm{~kg} \mathrm{tree}^{-1}$, which corresponds to $\mathrm{C}$ storage density ranged from 0.17-37-ton $\mathrm{ha}^{-1}$. The $\mathrm{C}$ density in $P$. pumila increased with crown density instead of stem density along increasing altitudinal gradients and increasing RCD. Hence, the crown density and diameter of a $P$. pumila plant can be used to predict the above-ground $\mathrm{C}$ density of its natural population.
\end{abstract}

Keywords: C sequestration; canopy tree; ecotone; global warming; treeline

\section{Introduction}

As an important carbon $(\mathrm{C})$ reservoir, the alpine biomes are extremely sensitive to ongoing climate change (IPCC, 2014). Climate change has a negative impact on alpine, which affects $\mathrm{C}$ sequestration (Greenwood and Jump, 2014). There has been less attention given to the effect of climate change on alpine habitats compared to the arctic tundra and boreal ecosystems (Britton et al., 2011). Although ambient C pools have been studied in degraded alpine grassland ecosystems that are experiencing anthropogenic pressures (Wen et al., 2013), C pools in other types of alpine communities are still unclear. Forests contain more than $45 \%$ of terrestrial C (Bonnan, 2008; Wei and He, 2021). Projected future climate change will continue to alter C

Received: 02 Jun 2021. Received in revised form: 03 Aug 2021. Accepted: 09 Aug 2021. Published online: 18 Aug 2021.

From Volume 49, Issue 1, 2021, Notulae Botanicae Horti Agrobotanici Cluj-Napoca journal uses article numbers in place of the traditional method of continuous pagination through the volume. The journal will continue to appear quarterly, as before, with four annual numbers. 
storage in forests (He et al., 2020; Manusch et al., 2014). There is a knowledge gap about forest C storage in sub-alpine regions (Wagner et al., 2015).

Gross primary production (GPP) in terrestrial ecosystem is the largest $\mathrm{CO}_{2}$ flux that supports ecosystem functions. Results from the biosphere model suggest a strong relationship between GPP and precipitation at the global scale (Beer et al., 2010). At high-elevation mountain regions, global warming may have caused a depletion of stored $\mathrm{C}$ in alpine vegetation through species extinction and diversity decline (Grabherr et al., 1994; IPCC, 2007). In contrast, in alpine tundra ecosystems, biomass, cover, and abundance in dwarf trees and shrubs were found to increase over the past century (Myers-Smith et al., 2011). There is no way to determine the whole $\mathrm{C}$ pool in alpine tundra ecosystems because of a lack of species-specific response of $\mathrm{C}$ storage in alpine shrub plants.

Pinus pumila (Pall.) Regel is known as the alpine dwarf-pine (He et al., 2021). They live mainly in the alpine zones of Japan, eastern Siberia, and mid-west Europe (Sano et al., 1977). Current understanding of C storage in P. pumila mainly comes from relative comparison with other plant biomes (Okitsu, 1985; Makoto et al., 2016). For example, biomass $C$ storage in $P$. pumila was surmised to be 10 times larger compared to other alpine plants in the krummholz zone of Japan (Okitsu, 1985). In the northern Amur region of Far East Russia, above-ground productivity of $P$. pumila was found to be greater than that in local coniferous trees (Makoto et al., 2016). Currently, there is limited information on the direct estimate of $\mathrm{C}$ storage in $P$. pumila populations. This is because its natural population has a very high density that makes field investigation nearly impossible. Recent reports revealed that $P$. pumila has expanded through local fellfield edges and snow-beds over the past three decades, increasing its distribution area by $14 \%$ (Amagai et al., 2015). This invasion may not have affected local fine root biomass and soil C storage (Makoto et al., 2016), but the effects on shoot $\mathrm{C}$ storage is still unclear. It is necessary to estimate the above-ground $\mathrm{C}$ storage in $P$. pumila to evaluate the impact of its expansion on $\mathrm{C}$ pools in endemic tundra plants at alpine regions.

Above-ground growth of $P$. pumila might be sensitive to elevation in alpine zones (Sano et al., 1977; Takhashi, 2003; Amagai et al., 2015) because annual shoot elongation was found to be driven by early summer temperature (from early June to late July) (Sano et al., 1977; Takahashi, 2003; Amagai et al., 2015). Temperature and other abiotic and biotic factors change as a gradient along mountain elevation (Guo et al., 2019; Wei et al., 2019, 2021b). P. pumila poorly tolerates even slight shading (Moskalyuk, 2008); hence its above-ground growth is depressed under tall tree canopies (Okuda et al., 2008). Therefore, P. pumila populations showed two types of vegetative growth patterns. At high altitudes, like other alpine plants, the height of P. pumila was depressed (Takahashi and Yoshida, 2009); at low altitudes, they dominate the undergrowth stratum in the open space to avoid tall tree shade (Takahashi, 2003; Okuda et al., 2008). Aboveground C storage in $P$. pumila is shaped by not only physical factors but also, more importantly, change along the altitudinal gradient.

P. pumila mainly dwells in deforested areas in the boreal subalpine belt, which is characterized by strong wind and heavy snow accumulation in winter and in spring (Okitsu and Ito, 1989). In cold seasons, P. pumila shoots are buried under snow which helps them to escape the desiccating and freezing impacts of winter winds (Moskalyuk, 2008). Therefore, dominancy of $P$. pumila diminished gradually from wind-exposed sites to snowdepositing sites (Okitsu and Ito, 1984). Given that $P$. pumila plants have dense and compact crowns carrying thick needles (Moskalyuk, 2008) that cover the forest floor (Takahashi, 2003), crown density can be an indicator of the distribution of $P$. pumila communities. Although the height of dwarf pines does not make it inconvenient to measure whole-tree $\mathrm{C}$ storage, the variance in the density of individuals at different altitudes still hinders the precision of $\mathrm{C}$ storage estimates on $P$. pumila in large populations.

In China, forests were estimated to have a biomass C sink of 1896 Tg during 1977-2008 with an annual $\mathrm{C}$ sink of $70.2 \mathrm{Tg}$ year $^{-1}$ and was projected to sequester $\mathrm{C}$ at this annual rate until 2050 (Chen et al., 2016). However, the estimate on $\mathrm{C}$ storage in alpine regions' tree community is still limited. In this study, P. pumila was investigated for above-ground growth along the altitude gradient to estimate their above-ground $\mathrm{C}$ storage 
using empirical allometric growth models. The purpose is to fill the knowledge gap on above-ground $\mathrm{C}$ storage in P. pumila.

\section{Materials and Methods}

\section{Study site}

The study area is located in the Great Khingan Mountains (51 $\left.39^{\prime}-51^{\circ} 54^{\prime} \mathrm{N}, 121^{\circ} 36^{\prime}-122^{\circ} 07^{\prime} \mathrm{E}\right) 45$ $120 \mathrm{~km}$ to the north of Genhe, Hulun Buir, Inner Mongolia, Northeast China. Local terrain consists of alpine and sub-alpine ecosystems in altitudes between 800-1500 m a.s.l. Ambient investigation was conducted on $P$. pumila communities with different crown densities (CDs) (20-90\%) at upper (1500 m above sea level [a.s.l.]) and lower altitudes $(800 \mathrm{~m}$ a.s.l.). The site area is at a cold temperate climate zone, where average temperature is $-5.3^{\circ} \mathrm{C}$, annual precipitation ranges between $50 \mathrm{~mm}$ and $80 \mathrm{~mm}$, and the annual frost-free period is about 90 days. Lands are highly covered by forests (92\%). Dominant trees include Larix gmelinii (Rupr.) Rupr., Pinus sylvestris L., Betula platyphylla Sukaczev, and Populus davidiana.

\section{Data investigation}

A pre-investigation was conducted before the study and all $P$. pumila communities were classified into four CDs $(20-30 \%, 40-50 \%, 60-70 \%$, and 80-90\%) (Figure 1). A total of 12 research plots, $50 \times 50 \mathrm{~m}$ in size, were created from 24 to 31 October, 2017 (Table 1). Each group of three plots were randomly placed as a replicate for one $C D$ classification. Five sub-plots, spaced $10 \times 10 \mathrm{~m}$, were established at the four corners and the center of each plot. Every individual $P$. pumila plant in one sub-plot was investigated for height, root-collar diameter (RCD), crown area (CA), and stem number. Height was measured as the length between the tip of the main stem and the root-collar. RCD was measured as the basal diameter of the main stem. Crown area was calculated as the product of largest crown length and width. The height, RCD, and CA values of the five subplots were averaged to obtain their respective mean values for the overall plot. Similarly, the stems in the five sub-plots were summed to obtain the stem number of the plot. Stem density (SD) was then calculated by dividing $250 \mathrm{~m}^{2}$ from the plot stem number. In total, $6231 \mathrm{P}$. pumila individuals were measured from all 60 sub-plots.
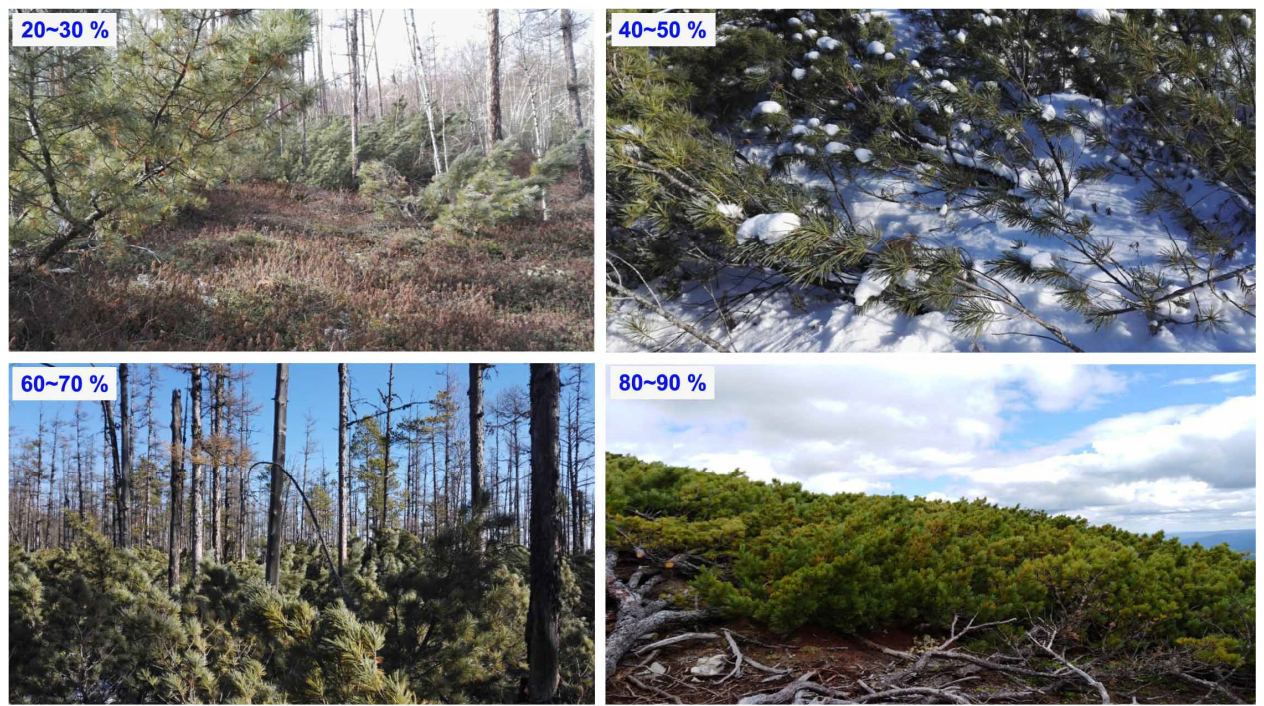

Figure 1. Stands of natural distributed Pinus pumila communities with different characteristics of crown densities 
Table 1. The field condition of Pinus pumila sites

\begin{tabular}{|c|c|c|c|c|c|c|c|}
\hline $\begin{array}{c}\text { Site } \\
\text { No. }\end{array}$ & Investing date & $\begin{array}{c}\text { Latitude } \\
(\mathrm{N})\end{array}$ & $\begin{array}{c}\text { Longitude } \\
(\mathrm{E})\end{array}$ & $\begin{array}{c}\mathrm{CD}^{1} \\
(\%)\end{array}$ & $\begin{array}{c}\text { Altitude } \\
(\mathrm{m})\end{array}$ & $\begin{array}{c}\text { Slope } \\
\text { aspect }\end{array}$ & $\begin{array}{c}\text { Slope } \\
\text { position }\end{array}$ \\
\hline 1 & 25 Oct. 2017 & $51^{\circ} 48^{\prime} 25^{\prime \prime}$ & $122^{\circ} 04^{\prime} 19^{\prime \prime}$ & 20 & 878 & East & Medium-low \\
\hline 2 & 26 Oct. 2017 & $51^{\circ} 49^{\prime} 49^{\prime \prime}$ & $122^{\circ} 02^{\prime} 54^{\prime \prime}$ & 30 & 997 & Southwest & Medium-low \\
\hline 3 & 31 Oct. 2017 & $51^{\circ} 39^{\prime} 06^{\prime \prime}$ & $122^{\circ} 00^{\prime} 12^{\prime \prime}$ & 20 & 872 & North & Low \\
\hline 4 & 26 Oct. 2017 & $51^{\circ} 49^{\prime} 24^{\prime \prime}$ & $122^{\circ} 03^{\prime} 48^{\prime \prime}$ & 50 & 918 & East & Medium-low \\
\hline 5 & 28 Oct. 2017 & $51^{\circ} 52^{\prime} 12^{\prime \prime}$ & $121^{\circ} 41^{\prime} 25^{\prime \prime}$ & 40 & 933 & East & Medium-low \\
\hline 6 & 31 Oct. 2017 & $51^{\circ} 39^{\prime} 07^{\prime \prime}$ & $122^{\circ} 00^{\prime} 04^{\prime \prime}$ & 40 & 916 & North & Medium-low \\
\hline 7 & 26 Oct. 2017 & $51^{\circ} 49^{\prime} 49^{\prime \prime}$ & $122^{\circ} 04^{\prime} 24^{\prime \prime}$ & 60 & 1115 & - & Top \\
\hline 8 & 29 Oct. 2017 & $51^{\circ} 41^{\prime} 24^{\prime \prime}$ & $122^{\circ} 07^{\prime} 01^{\prime \prime}$ & 70 & 1125 & Southwest & Up \\
\hline 9 & 30 Oct. 2017 & $51^{\circ} 46^{\prime} 01^{\prime \prime}$ & $121^{\circ} 36^{\prime} 01^{\prime \prime}$ & 70 & 923 & Southwest & Valley \\
\hline 10 & 24 Oct. 2017 & $51^{\circ} 50^{\prime} 36^{\prime \prime}$ & $122^{\circ} 02^{\prime} 12^{\prime \prime}$ & 90 & 1505 & Southwest & Up \\
\hline 11 & 27 Oct. 2017 & $51^{\circ} 54^{\prime} 36^{\prime \prime}$ & $121^{\circ} 43^{\prime} 42^{\prime \prime}$ & 80 & 1209 & Southwest & Up \\
\hline 12 & 30 Oct. 2017 & $51^{\circ} 46^{\prime} 18^{\prime \prime}$ & $121^{\circ} 35^{\prime} 43^{\prime \prime}$ & 90 & 994 & - & Top \\
\hline
\end{tabular}

${ }^{1} \mathrm{SC}$, crown density.

\section{Above-ground C estimation}

Above-ground $\mathrm{C}$ storage was estimated for each $P$. pumila using biomass allometric growth models summarized by Li et al. (2010). The models were empirically used for shrub species in Northeast China. The botanical nomenclature of these species and the empirical equations are listed in Table 2. Above-ground $\mathrm{C}$ storage in P. pumila was estimated ten times. The results therefrom allow for comparison and screening for the best fitted estimates.

Table 2. The estimation models for shoot carbon (C) stock in $P$. pumila using empirical allometric growth models

\begin{tabular}{|l|c|c|c|}
\hline \multicolumn{1}{|c|}{ Applicative species } & Allometric growth model & $\begin{array}{c}\text { Height } \\
\text { range }(\mathrm{m})\end{array}$ & $\begin{array}{c}\text { Diameter } \\
\text { range } \\
(\mathrm{cm})\end{array}$ \\
\hline Euonymus verrucosoides $^{1}$ & $C_{\text {shoot }}=0.152 \times D^{2.505}$ & $0.67 \sim 4.09$ & $0.5 \sim 4.8$ \\
\hline${\text { E. } \text { alatus }^{1}}$ & $C_{\text {shoot }}=0.095 \times D^{2.655}$ & $0.33 \sim 3.21$ & $0.4 \sim 5.1$ \\
\hline Corylus mandshurica $^{1}$ & $C_{\text {shoot }}=0.044 \times D^{2.957}$ & $0.34 \sim 3.95$ & $0.3 \sim 3.8$ \\
\hline${\text { Viburnum } \text { burejaeticum }^{1}}^{1}$ & $C_{\text {shoot }}=88.627 \times C A H^{0.646}$ & $0.59 \sim 3.54$ & $0.4 \sim 3.1$ \\
\hline Lonicera maackii $^{1}$ & $C_{\text {shoot }}=180.832 \times C A^{1.395}$ & $0.67 \sim 4.41$ & $0.4 \sim 7.4$ \\
\hline Spiraea ussuriensis $^{1}$ & $C_{\text {shoot }}=93.014 \times C A H^{0.912}$ & $0.55 \sim 1.48$ & $0.3 \sim 1.0$ \\
\hline Acanthopanax senticosus $^{1}$ & $C_{\text {shoot }}=132.269 \times C A H^{0.838}$ & $0.36 \sim 2.97$ & $0.3 \sim 1.0$ \\
\hline Deutzia parviflora var. amurensis $^{1}$ & $C_{\text {shoot }}=99.779 \times C A H^{0.957}$ & $0.26 \sim 2.25$ & $0.2 \sim 1.6$ \\
\hline Philadelphus schrenkii $^{1}$ & $C_{\text {shoot }}=34.54 \times H^{2.51}$ & $0.18 \sim 3.13$ & $0.3 \sim 2.7$ \\
\hline Sorbaria sorbifolia $^{1}$ & $C_{\text {shoot }}=68.018 \times C A H^{1.021}$ & $0.55 \sim 1.48$ & $0.5 \sim 1.9$ \\
\hline
\end{tabular}

${ }^{1}$ Adapted from Li et al. $(2010) ;{ }^{2} C A$, crown area $\left(\mathrm{m}^{2}\right)$.

\section{Data analysis}

All of the data calculation and analysis were performed using SAS software (SAS Institute Inc., Cary, NC, USA). The mean, above-ground $\mathrm{C}$ density for each plot $(A C D)$ was calculated using the following equation (Zhang et al., 2015):

$$
A C D=\frac{\sum_{i=1}^{n} \sum_{j=1}^{m} \frac{C_{i j}}{P A}}{n}
$$


where $C_{i j}$ is the $\mathrm{C}$ density for the $\dot{t}$ h $P$. pumila unit $\left(\mathrm{kg} \mathrm{unit}^{-1}\right)$ in the $i$ th sub-plot; $P A$ is the project area of the sub-plot $\left(P A=100 \mathrm{~m}^{2}\right) ; m$ is the total number of units in the sub-plot; $n$ is the total number of sub-plots $(n=5)$. With the goal of evaluating an accurate estimation, the six sets of data about $\mathrm{C}$ storage were analyzed for the principal components (PCs) using the 'princomp' procedure. Thereafter, datasets with the greatest similarity in distribution patterns were averaged to estimate the $\mathrm{C}$ storage.

The normal distribution of data was checked by the Shapiro-Wilk test using the 'univariate' procedure. Indices with normally distributed data were compared among CDs using analysis of variance (ANOVA). Unnormally distributed data were compared in pairs with Wilcoxon Signed-Rank test (Guan et al., 2017). The significance was taken at the 0.05 level for ANOVA, and at the 0.0083 level due to the Bonferroni correction for six pairs of comparison. The Spearman correlations were analysed for all data using the 'corr' procedure.

\section{Results}

\section{Screening of shoot biomass estimate models}

According to the PC analysis on above-ground C estimates, the first two PCs accounted for $94.53 \%$ of the total data variation. In the first axis, all estimated $\mathrm{C}$ storage from the ten models showed the same trend of data variation (Figure 2). In the second axis, estimated data on C storage of Euonymus verrucosoides, E. alatus, Philadelphus schrenkii, and Corylus mandshurica showed different variation patterns with the other six species. Therefore, assessment of $\mathrm{C}$ storage can be classified into two groups according to the PC results.

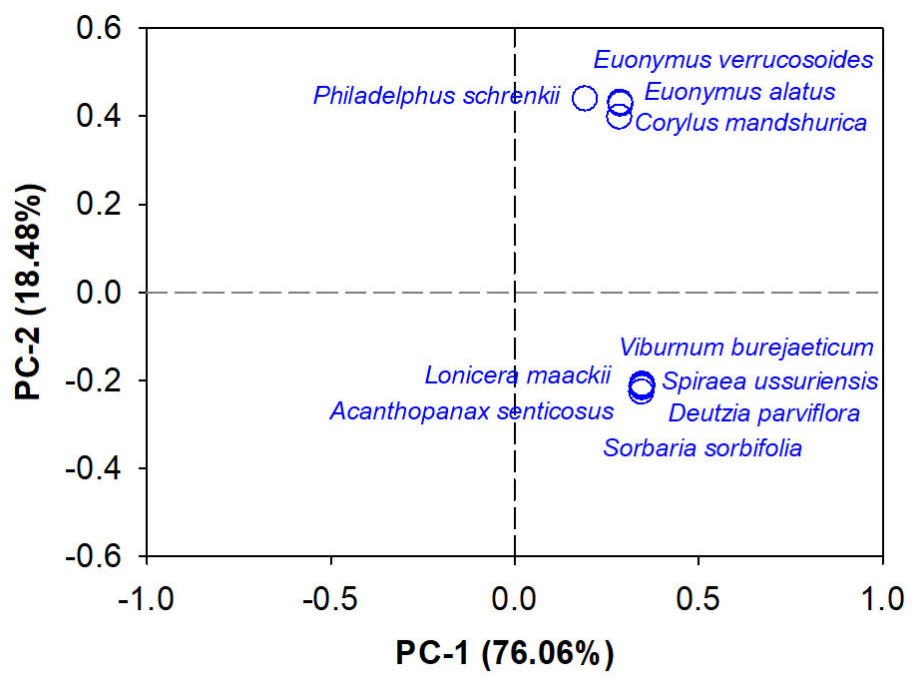

Figure 2. The principal component (PC) analysis on estimated above-ground $\mathrm{C}$ storage using empirical allometric growth models on ten local shrubs

Botanical nomenclature is supplied beside the scattered dots

\section{Above-ground growth}

Among above-ground indices, only data on height followed the normal distribution (W=0.9689; $\left.P_{\mathrm{r}}<\mathrm{W}, 0.1293\right)$. Above-ground height in CDs of $20-30 \%$ were about $210 \%$ greater than above-ground height in CDs of 40-50 \% and 60-70 \% (Figure 3A). RCD in denser CDs was 6.5-7 times higher than RCD in CDs of 20-30 \% (Signed-Rank $S=60 ; P_{\mathrm{r}} \geq|S|,<0.0001$ ) (Figure 3B). CA was greatest in CDs of 80-90\%, which was $17-23 \%$ higher than that in sparser CDs (Signed-Rank $S=60 ; P \mathrm{r} \geq|S|,<0.0001$ ) (Figure 3C). SD increased at a rate of $20-40 \%$ with the increase of $\mathrm{CD}$ (Figure 3D). 

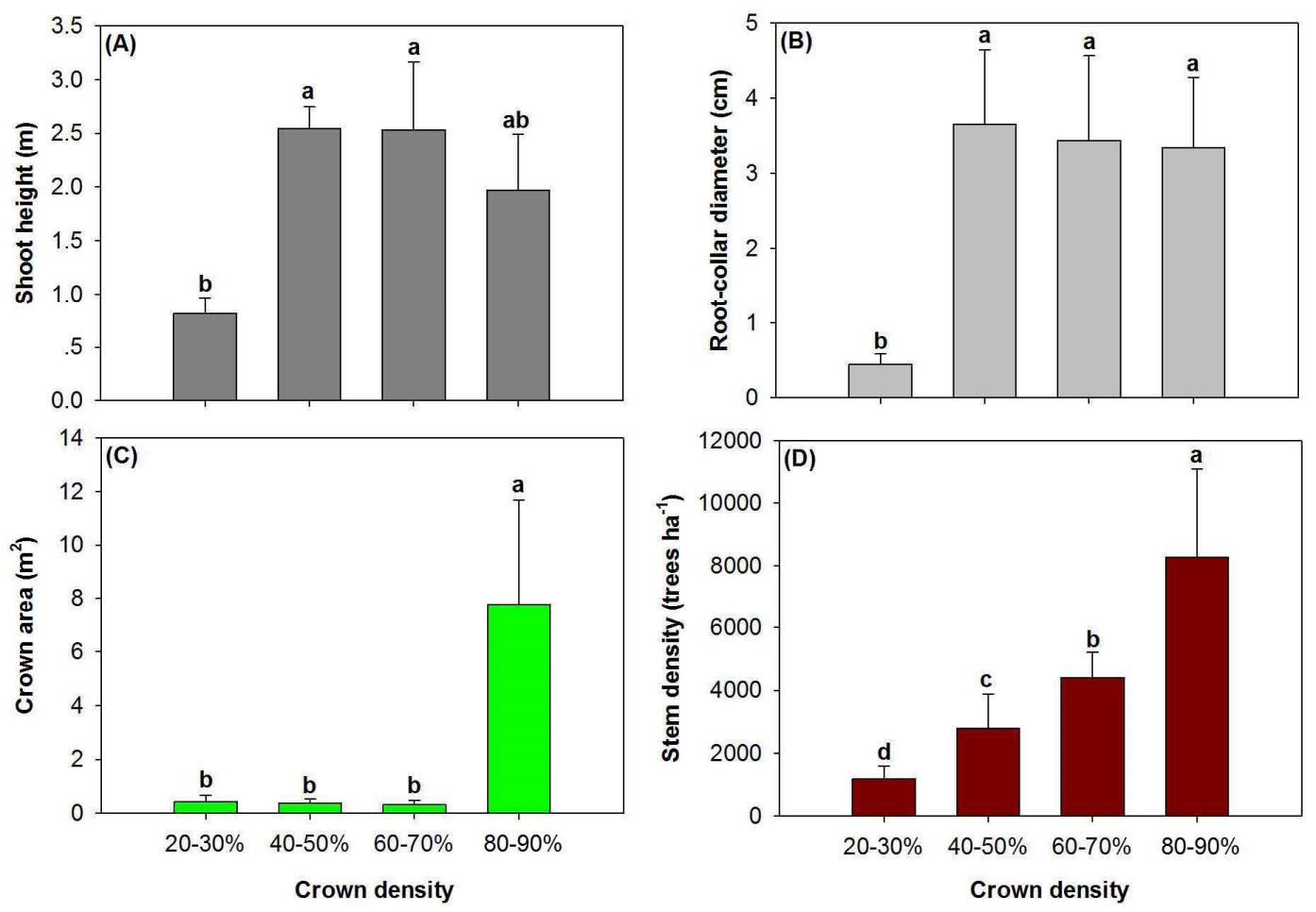

Figure 3. Above-ground growth parameters of $P$. pumila in response to different crown densities Different letters indicate significant differences at 0.05 level for above-ground height $(A)$ through analysis of variance (ANOVA), and at 0.0083 level for root-collar diameter (B), crown area (C), and stem density (D) through pairedcomparison using the Wilcoxon Signed-Rank test.

\section{The relationship between altitude and above-ground indices}

A Pearson correlation was found between altitude and $\operatorname{CD}(n=12 ; R=0.6920 ; P=0.0127)$, while a Spearman correlation was found between altitude and $\operatorname{SD}(n=12 ; R=0.7273 ; P=0.0074)$ and between altitude and CA $(n=12 ; R=0.6294 ; P=0.0283)$. Therefore, the relationship between altitude and $\mathrm{CD}$ can be described by a linear regression model (Figure 4); the relationship between altitude and log-transformed SD can be described by a type II 2-parameter logarithmic equation; the relationship between altitude and square root of CA can be described by a 2-parameter single-exponential-growth equation. In addition, height was found to be positively correlated with RCD $(n=12 ; R=0.9390 ; P<0.0001)$.

\section{The relationship between crown density and above-ground indices}

A Pearson correlation was found between $\mathrm{CD}$ and the square root of $\operatorname{RCD}(n=12 ; R=0.6421$; $P=0.0244)$ and between $\mathrm{CD}$ and the square root of $\mathrm{CA}(n=12 ; R=0.6624 ; P=0.0189)$, while a Spearman correlation was found between CD and log-transformed SD $(n=12 ; R=0.9543 ; P<0.0001)$. Therefore, the relationship between $C D$ and the square root of RCD or the square root of CA can both be described by a linear regression model (Figure 5); the relationship between $\mathrm{CD}$ and log-transformed SD can be described by a 2-parameter exponential-growth equation (Figure 5). 


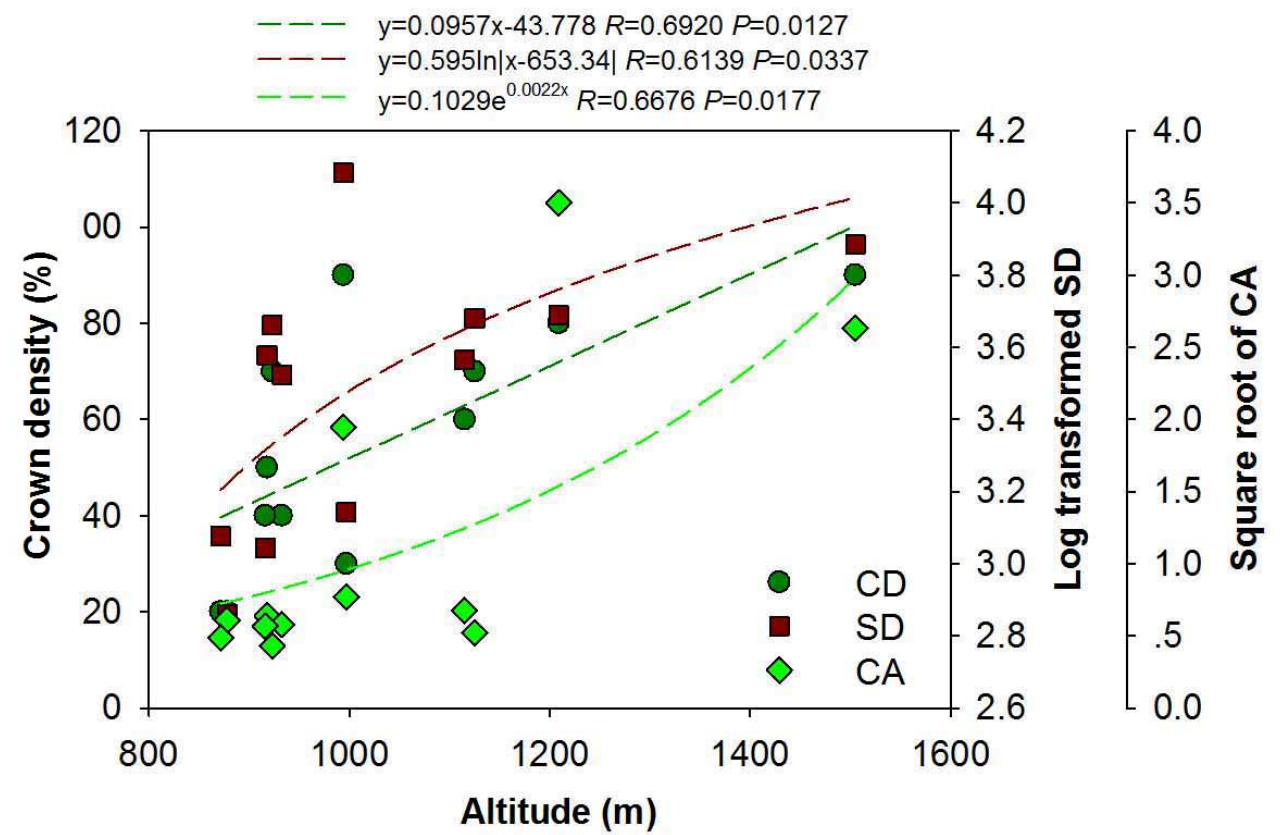

Figure 4. The best-fit curves for correlations of altitude with indices of canopy density, log-transformed stem density (SD), and the square-root of canopy area (CA) in $P$. pumila populations

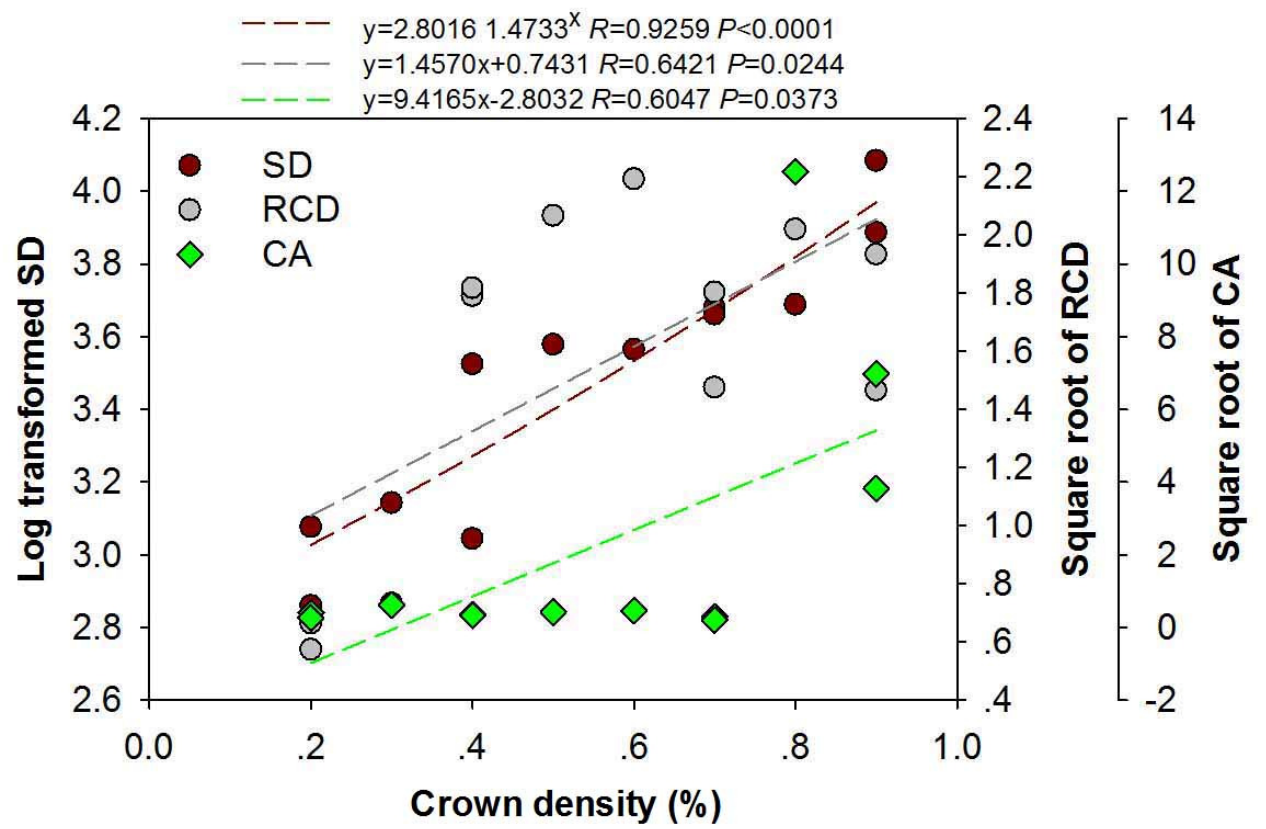

Figure 5. The best-fit curves for correlations of crown density with indices of log-transformed stem density (SD), the square-root of root-collar diameter (RCD), and the square-root of canopy area (CA) in P. pumila populations

\section{The estimation of above-ground $C$ storage}

Using the models in Table 2, ten estimates of above-ground biomass were made (Table 3). These results can be used for PC analysis for classification (Figure 2). 
The type-I group contained results from models on E. verrucosoides, E. alatus, P. schrenkii, and $C$. mandshurica, and the type-II group contained results from models on the other six species (Table 4). Aboveground C storage in P. pumila plants with CDs of $20-30 \%$ tended to have the lowest C storage, independent of the model used for estimation (Table 4). In sites with CDs denser than $30 \%$, the $\mathrm{C}$ storage estimated by both Type-I and Type-II models was not statistically different for different CDs. C storages in other sites were all higher than the $\mathrm{C}$ storage of the site with a CD of 20-30\% in both individual plant and site density. The mean value of above-ground C storage from the Type-I and Type-II models was higher in sites with CDs of 80-90\% than that in sites with CDs of $20-30 \%$.

Table 3. The estimations for shoot carbon (C) stock in $P$. pumila using empirical allometric growth models

\begin{tabular}{|l|c|c|c|c|c|}
\hline Percent of crown density & $\mathrm{Ev}^{1}$ & $\mathrm{Ea}^{2}$ & $\mathrm{Cm}^{3}$ & $\mathrm{Vb}^{4}$ & $\mathrm{Lm}^{5}$ \\
\hline $20 \sim 30 \%$ & $0.08 \pm 0.18 \mathrm{c}^{6}$ & $0.08 \pm 0.18 \mathrm{~b}$ & $0.07 \pm 0.18 \mathrm{~b}$ & $0.19 \pm 0.21 \mathrm{~b}$ & $0.26 \pm 0.25 \mathrm{~b}$ \\
\hline $40 \sim 50 \%$ & $17.62 \pm 17.72 \mathrm{~b}$ & $21.00 \pm 22.33 \mathrm{a}$ & $36.38 \pm 42.99 \mathrm{ab}$ & $0.50 \pm 0.37 \mathrm{~b}$ & $0.40 \pm 0.31 \mathrm{~b}$ \\
\hline $60 \sim 70 \%$ & $21.52 \pm 16.36 \mathrm{ab}$ & $25.34 \pm 20.32 \mathrm{a}$ & $42.79 \pm 39.18 \mathrm{ab}$ & $0.68 \pm 0.43 \mathrm{~b}$ & $0.57 \pm 0.40 \mathrm{~b}$ \\
\hline $80 \sim 90 \%$ & $33.46 \pm 22.96 \mathrm{a}$ & $40.71 \pm 33.33 \mathrm{a}$ & $77.35 \pm 87.61 \mathrm{a}$ & $21.41 \pm 7.36 \mathrm{a}$ & $63.48 \pm 25.62 \mathrm{a}$ \\
\hline & & & & & \\
\hline $20 \sim 30 \%$ & $\mathrm{Su}^{7}$ & $\mathrm{As}^{8}$ & $\mathrm{Dpa}^{9}$ & $\mathrm{Ps}^{10}$ & $\mathrm{Ss}^{11}$ \\
\hline $40 \sim 50 \%$ & $0.22 \pm 0.25 \mathrm{~b}$ & $0.28 \pm 0.29 \mathrm{~b}$ & $0.24 \pm 0.27 \mathrm{~b}$ & $0.24 \pm 0.36 \mathrm{~b}$ & $0.19 \pm 0.23 \mathrm{~b}$ \\
\hline $60 \sim 70 \%$ & $0.74 \pm 0.59 \mathrm{~b}$ & $0.96 \pm 0.75 \mathrm{~b}$ & $0.84 \pm 0.68 \mathrm{~b}$ & $3.76 \pm 2.86 \mathrm{a}$ & $0.62 \pm 0.51 \mathrm{~b}$ \\
\hline $80 \sim 90 \%$ & $1.00 \pm 0.68 \mathrm{~b}$ & $1.29 \pm 0.86 \mathrm{~b}$ & $1.14 \pm 0.78 \mathrm{~b}$ & $5.59 \pm 3.26 \mathrm{a}$ & $0.84 \pm 0.59 \mathrm{~b}$ \\
\hline
\end{tabular}

${ }^{1} \mathrm{Ev}$, Euonymus verrucosoides, ${ }^{2} \mathrm{Ea}$, Euonymus alatus; ${ }^{3} \mathrm{Cm}$, Corylus mandshurica; ${ }^{4} \mathrm{Vb}$, Viburnum burejaeticum; ${ }^{5}$ Lm, Lonicera maackii; ${ }^{6}$ Different letters indicate significant difference adjusted by Bonferroni correction; ${ }^{7} \mathrm{Su}, S_{\text {piraea }}$ ussuriensis; ${ }^{8}$ As, Acanthopanax senticosus, ${ }^{9} \mathrm{Dpa}$, Deutzia parviflora var. amurensis, ${ }^{10} \mathrm{Ps}$, Philadelphus schrenkii; ${ }^{11}$ Ss, Sorbaria sorbifolia.

Table 4. The estimated $\mathrm{C}$ stock (mean \pm S.E.) in $P$. pumila distributed in sites with different crown densities $(n=12)$

\begin{tabular}{|l|c|c|c|}
\hline \multicolumn{1}{|c|}{ Percent of crown density } & Type-I & \multicolumn{2}{c|}{ Mype-II } \\
\hline & \multicolumn{3}{|c|}{ Unit tree storage $\left(\mathrm{kg} \mathrm{tree}^{-1}\right)$} \\
\hline $20 \sim 30 \%$ & $0.03 \pm 0.04 \mathrm{~b}$ & $0.07 \pm 0.05 \mathrm{~b}$ & $0.05 \pm 0.05 \mathrm{~b}$ \\
\hline $40 \sim 50 \%$ & $2.52 \pm 2.16 \mathrm{a}$ & $0.09 \pm 0.05 \mathrm{~b}$ & $1.31 \pm 1.10 \mathrm{ab}$ \\
\hline $60 \sim 70 \%$ & $2.18 \pm 1.62 \mathrm{a}$ & $0.08 \pm 0.05 \mathrm{~b}$ & $1.13 \pm 0.83 \mathrm{bc}$ \\
\hline $80 \sim 90 \%$ & $2.74 \pm 3.43 \mathrm{a}$ & $2.19 \pm 1.54 \mathrm{a}$ & $2.46 \pm 2.42 \mathrm{a}$ \\
\hline$F_{\text {value }}$ & 3.72 & 21.40 & 5.76 \\
\hline$P_{\text {value }}$ & 0.0164 & $<0.0001$ & 0.0017 \\
\hline & & C storage density (ton ha $\left.{ }^{-1}\right)$ & $0.17 \pm 0.21 \mathrm{~b}$ \\
\hline $20 \sim 30 \%$ & $0.12 \pm 0.19 \mathrm{~b}$ & $0.23 \pm 0.24 \mathrm{~b}$ & $10.18 \pm 10.98 \mathrm{~b}$ \\
\hline $40 \sim 50 \%$ & $19.69 \pm 21.45 \mathrm{a}$ & $0.68 \pm 0.53 \mathrm{~b}$ & $12.36 \pm 10.14 \mathrm{~b}$ \\
\hline $60 \sim 70 \%$ & $23.81 \pm 19.72 \mathrm{a}$ & $0.92 \pm 0.62 \mathrm{~b}$ & $37.14 \pm 23.87 \mathrm{a}$ \\
\hline $80 \sim 90 \%$ & $39.15 \pm 35.93 \mathrm{a}$ & $35.13 \pm 13.90 \mathrm{a}$ & 14.23 \\
\hline$F_{\text {value }}$ & 5.52 & 70.31 & $<0.0001$ \\
\hline$P_{\text {value }}$ & 0.0022 & $<0.0001$ & \\
\hline
\end{tabular}

The relationship between estimated C storage and other indices

According to the Spearman correlation model, mean estimated C density is positively correlated with indices of altitude and CD according to the Spearman correlation model (Table 5). No correlation was found between above-ground $\mathrm{C}$ density and $\mathrm{SD}$. For individual growth indices, both above-ground height and $\mathrm{RCD}$ 
were found to have a positive relationship with mean values of estimated C storage. No relationship was detected between CA and estimated C storage.

Table 5. Spearman correlation analysis on the relationship between estimated C stock density and distribution parameters of $P$. pumila $(n=12)$

\begin{tabular}{|c|c|c|c|}
\hline Independent & $\mathrm{C}$ density ${ }^{1}$ & Independent & C density \\
\hline \multicolumn{2}{|c|}{ Site characteristic } & \multicolumn{2}{|c|}{ Individual growth } \\
\hline Altitude & $\begin{aligned} R^{2} & =0.3787^{2} \\
P & =0.0332\end{aligned}$ & Height & $\begin{aligned} R^{2} & =0.7887 \\
P & =0.0001\end{aligned}$ \\
\hline $\mathrm{CD}^{3}$ & $\begin{array}{c}R^{2}=0.3499 \\
P=0.0428\end{array}$ & $\mathrm{RCD}$ & $\begin{array}{c}R^{2}=0.9178 \\
P<0.0001\end{array}$ \\
\hline $\mathrm{SD}^{4}$ & $\begin{array}{c}R^{2}=0.2678 \\
P=0.0849\end{array}$ & $\mathrm{CA}$ & $\begin{aligned} R^{2} & =0.2396 \\
P & =0.1063\end{aligned}$ \\
\hline
\end{tabular}

${ }^{1}$ unit, ton ha ${ }^{-1} ;{ }^{2}$ Bold numbers indicate significant correlation; ${ }^{3} \mathrm{CD}$, crown density; ${ }^{4} \mathrm{SD}$, stem density.

\section{Discussion}

Current knowledge on $P$. pumila communities is mainly derived from reports on natural distribution in Japan and Siberia. In central Japan $\left(35^{\circ} \mathrm{N}\right)$, P. pumila distributes in mountain regions with altitudes from 2400 to $2850 \mathrm{~m}$ a.s.l. (Takahashi, 2003; Takahashi and Yoshida, 2009); in northern Japan (43 $\left.{ }^{\circ} \mathrm{N}\right)$, P. pumila distributes between altitudes of $1500 \mathrm{~m}$ and $2000 \mathrm{~m}$ a.s.l. (Okitsu and Ito, 1984, 1989; Amagai et al., 2015). In Siberia $\left(54^{\circ} \mathrm{N}\right)$, P. pumila distributes between altitudes of 250-500 m a.s.l. (Moskalyuk, 2008; Makoto et al., 2016). These results suggest that the altitudinal distribution of $P$. pumila tends to decline with the increase of latitude. In this study, $P$. pumila distributes in altitudes of 800-1500 $\mathrm{m}$ a.s.l. in the Great Khingan Mountains $\left(51^{\circ} \mathrm{N}\right)$. Fang et al. (2015) also found the distribution of undergrowth $P$. pumila in altitudes up to $1504 \mathrm{~m}$ a.s.l. in this region. Both the altitude and latitude of our $P$. pumila distribution fall between the altitude and latitude of $P$. pumila in Japan and Russia. Our $P$. pumilastands with CDs of $60-70 \%$ that were located around treelines, but those in the $80-90 \%$ CD region locate near the alpine tundra and grassland (Figure 1).

Our $\mathrm{C}$ storage estimations had larger standard deviations than expected. This is because $P$. pumila has a high ontogeny among individuals on the basis of a high density in populations. In addition, our results were estimated in which errors may accumulate from the initial estimate to across-model averages. We found that estimated above-ground $\mathrm{C}$ storage had similar variation across Type-I models. These $\mathrm{C}$ estimation models all involved the height or diameter of a shrub, but the Type-II models employed the CA as a parameter. Therefore, using CA to estimate $\mathrm{C}$ storage created more variation in data compared to $\mathrm{PC}$ analysis without $\mathrm{CA}$. Our sites were located along the altitude gradient, which had different relationship with RCD and CA, resulting in different responsive trends of estimated $\mathrm{C}$ storage by RCD and CA. Although the height of $P$. pumila did not correlate with other growth parameters, it was found to positively correlate with $\mathrm{C}$ storage which suggests that stem length positively contributes to above-ground $\mathrm{C}$ storage, independent of altitude gradient.

We did not find any relationship between altitudes and above-ground height for $P$. pumila. Our results disagree with those found in central Japan by Takahashi (2003) in spite no clear relationship was studied therein. Takahashi and Yoshida (2009) found that P. pumila were shorter in the upper distribution limit, but they did not study the relationship between height and altitude. Wang et al. (2017) measured 3500 dominant trees in Changbai Mountain, Northeast China, and found a very species-specific response regarding height along the altitude gradient. The height response of $P$. pumila to altitudinal gradient may be interrupted by either biotic factors (Takahashi and Yoshida, 2009) or canopy tree shading (Takahashi, 2003; Okuda et al., 2008). Specifically, Kajimoto (1993) found that the length of current above-grounds and needles showed apparent decreasing trends with increasing altitude. We did not distinguish above-ground parts by ages; hence, no significant response was revealed. However, because altitude was found to be positively correlated with CD (Figure 4), height response to altitudinal gradient can be surmised according to the regression model and the 
response to $\mathrm{CD}$ (Figure 3A). Height growth of $P$. pumila along the altitudinal gradient was positive from 800 $\mathrm{m}$ to $1200 \mathrm{~m}$, but was negative around $1500 \mathrm{~m}$.

We found a positive relationship between height and RCD in $P$. pumila. Similarly, Okitsu and Ito (1984) also found a positive relationship between height and annual increment index ( $\mathrm{RCD}^{2} \times$ Height). Wang et al. (2017) reported the linear relationship between height and diameter using data from 3500 dominant trees in Changbai Mountain, Northeast China. According to Sano et al.(1977), annual height and diameter growths of $P$. pumila were synchronized and both were driven by annual changes in climate. Like height, RCD did not respond to the latitudinal gradient (Figure 4), which corroborates Takahashi et al. (2012). Both height and RCD were lower in the site with CDs of 20-30\% than in sites with denser CDs (Figure 3). This was the result of stress caused by tall trees (Moskalyuk, 2008; Okuda et al., 2008; Takahashi et al., 2012).

Both SD and CA were positively correlated with altitude and CD in P. pumila. SD was also found to positively correlate with altitude because of the increasing depression of tall tree competition (Takahashi et al., 2012). The SD of $P$. pumila was mainly countered by the number of fascicle stems, which were sensitive to the low temperature and wind exposure (Kajimoto, 1993). Abundant needles contribute to the dense canopy (Uehara et al., 2012) but needle longevity is also sensitive to the harsh condition in high altitudes (Kajimoto, 1993). However, in our study, the biotic condition in the high altitude was not limiting enough to negatively impact the density and crown of $P$. pumila.

Our results revealed that the above-ground $\mathrm{C}$ density in $P$. pumila increased with altitude and CD, while individual C storage positively correlated with height and RCD. Similar to our results, Takahashi et al. (2012) reported a positive relationship between altitude and absolute above-ground dry mass accumulation. Because our main model for the estimation of $\mathrm{C}$ storage used height and RCD as input variables, $\mathrm{C}$ increased with height and RCD growth. Correlation analysis for coefficient of determination showed interesting results, wherein the estimation on above-ground $\mathrm{C}$ density depended on altitude and canopy density only by less than $40 \%$, but estimation on individual C storage depended on height and RCD by nearly $80-90 \%$. These results suggest that the precision of $\mathrm{C}$ storage estimation is higher using data from the individual growth than data from the population characteristics. The coefficient of determination for the correlation between CD and C storage density for $P$. pumila in Northeast China was lower than for the correlation between observed C density and C storage density in the forests of Western China (Yue et al., 2016). According to Beer et al. (2010), who summarized the data on $\mathrm{C}$ storage density in the terrestrial system, our $\mathrm{C}$ storage density may have been overestimated due to a low coefficient of determination (between 20-40\%). However, our results were reasonable because some seed sources of $P$. pumila individuals in our study were mature trees whose annual growth are faster than seedlings with larger canopy area and subsequently greater $\mathrm{C}$ storage estimation (Okitsu and Ito, 1984).

The stem of $P$. pumila plants is not as tall as the other Pinus spp. trees. It is necessary to develop some model to estimate their $\mathrm{C}$ storage because their density was too high in natural populations. However, although estimating $\mathrm{C}$ storage through empirical models is an operational approach for large-scale $\mathrm{C}$ estimates, we still have several uncertainties in the estimation of $\mathrm{C}$ storage. Firstly, to estimate $\mathrm{C}$ storage through allometric models, only one to two growth parameters needs to be involved, but above-ground biomass should be responsive to multiple morphological indices. Despite the heavy workload to measure every individual growth in one time, more measurements are needed for greater precision. The limit of public data about shrub C estimation in the study also hindered the improvement of estimation precision. Finally, the estimation of C storage can be enhanced by referring to the empirical models and biomass of sampling individuals.

According to the allometric growth model, it was found that the above-ground $\mathrm{C}$ density in $P$. pumila at sites with CDs over $30 \%$ was estimated to range $10-37-$ ton ha ${ }^{-1}$, which was much higher than that in CDs of 20-30\% (Table 4). Our C storage density was much higher than that in alpine grassland (0.19-0.54-ton ha $\left.{ }^{1}\right)$ (Wen et al., 2013) but close to that in alpine Picea crassifolia forest trees (43-ton ha ${ }^{-1}$ ) (Wagner et al., 2015) in Southwest China and sub-alpine broad-leaved trees in Switzerland (49-ton ha ${ }^{-1}$ ) (Manusch et al., 2014). However, our $\mathrm{C}$ storage density was much lower than that for above-ground live trees in temperate alpine 
forests (81-ton ha-1) (Bradford et al., 2009). Therefore, the estimating precision can be acceptable but more accurate estimation still needs large-scale measurements for dry mass.

\section{Conclusions}

This study analysed the density and above-ground growth of $6231 \mathrm{P}$. pumila units from 60 sub-plots $(10 \mathrm{~m} \times 10 \mathrm{~m})$, i.e. 12 plots $(50 \mathrm{~m} \times 50 \mathrm{~m})$, from main populations in Great Khingan Mountains, Inner Mongolia, Northeast China in late October, 2017. The allometric growth models were adapted for estimation using equations from local shrubs' general models in the research area. The variation of data in estimated aboveground $\mathrm{C}$ density depended on the model and whether canopy area was involved. As a result, above-ground $\mathrm{C}$ storage in a $P$. pumila unit ranged $0.05-2.46 \mathrm{~kg}_{\text {tree }}{ }^{-1}$, corresponding to $\mathrm{C}$ storage density ranged $0.17-37$-ton $\mathrm{ha}^{-1}$, respectively. The $\mathrm{C}$ density in $P$. pumila increased with crown density but not stem density along the increasing altitude gradient and increasing RCD. Hence, the crown density and diameter of a $P$. pumila plant can be grossly used to predict the above-ground $\mathrm{C}$ density of its natural population. Our data supplemented evidence to estimate the expansion of $\mathrm{C}$ pools in endemic tundra plants at alpine regions. Although our study is the first to estimate regional $\mathrm{C}$ storage in $P$. pumila, our data was limited to the study area. More studies are needed in the future on P. pumila communities in the Far East, Siberia, and the northern and central mountain regions of Japan to compare with our results because current studies are mainly conducted in these regions.

\section{Authors' Contributions}

Conceptualization: RC and FS; Data curation: RC, HY, and XP; Formal analysis: RC and FS; Funding acquisition: RC; Investigation: RC, HY, XP, and FS; Methodology: HY and FS; Project administration: RC; Resources: HY and XP; Software: XP and FS; Supervision: RC; Validation: HY and XP; Visualization: RC and FS; Writing - original draft: RC; W riting - review and editing: FS.

All authors read and approved the final manuscript.

\section{Acknowledgements}

The current study was supported by the Branch of Program of Investigation on S\&T Basic Resources Survey and Collection of Seed Resources for Pinus pumila (grant number: 2019FY100802_06), the Fundamental Research Funds for the Central Non-profit Research Institution of CAF (grant number: CAFYBB2016ZD009), Project of Research on the Mechanism for Genetic Regulation on Seed Growth and Development of Pinus pumila and CFERN\&BEIJING TECHNOSOLUTIONS Award Funds on Excellent Academic Achievement.

\section{Conflict of Interests}

The authors declare that there are no conflicts of interest related to this article. 
Cong R et al. (2021). Not Bot Horti Agrobo 49(3):12389

\section{References}

Amagai Y, Kaneko M, Kudo G (2015). Habitat-specific responses of shoot growth and distribution of alpine dwarf-pine (Pinus pumila) to climate variation. Ecological Research 30(6):969-977. https://doi.org/10.1007/s11284-0151299-6

Beer C, Reichstern M, Tomelleri E, Ciais P, Jung M, Carvalhais N, ... Papale D (2010). Terrestrial gross carbon dioxide uptake: global distribution and covariation with climate. Science 329(5993):834-838. https://doi.org/10.1126/science.1184984

Bonan GB (2008). Forests and climate change: forcings, feedbacks, and the climate benefits of forests. Science 320(5882):1444-1449. https://doi.org/10.1126/science.1155121.PMID:18556546

Bradford J, Weishampel P, Smith ML, Kolka R, Birdsey RA, Ollinger SV, Ryan MG (2009). Detrital carbon pools in temperate forests: magnitude and potential for landscape-scale assessment. Canadian Journal Forest Research 39:802-813. https://doi.org/10.1139/X09-010

Britton AJ, Helliwell RC, Lilly A, Dawson L, Fisher JM, Coull M, Ross J (2011) An integrated assessment of ecosystem carbon pools and fluxes across an oceanic alpine toposequence. Plant and Soil 345:287-302. https://doi.org/10.1007/s11104-011-0781-3

Chen L, Zhang CS, Xie GD, Liu CL, Wang HH, Li Z, Pei S, Qiao Q (2016). Vegetation carbon storage, spatial patterns and response to altitude in Lancang River Basin, Southwest China. Sustainability 8:110. https://doi.org/10.3390/su8020110

Fang L, Yang J, Zu JX, Li GC, Zhang JS (2015). Quantifying influences and relative importance of fire weather, topography, and vegetation on fire size and fire severity in a Chinese boreal forest landscape. Forest Ecology and Management 356:2-12. https://doi.org/10.1016/j.foreco.2015.01.011

Grabherr G, Gottfried M, Pauli H (1994). Climate effects on mountain plants. Nature $369: 448$. https://doi.org/10.1038/369448aO

Greenwood S, Jump AS (2014). Consequences of treeline shifts from the diversity and function of high altitude ecosystems. Artic, Antarctic and Alpine Research 46(4):829-840. https://doi.org/10.1657/1938-4246-46.4.829

Guan HM, Wei HX, He XY, Ren ZB, An BY (2017). The tree-species-specific effect of forest bathing on perceived anxiety alleviation of young-adults in urban forests. Annals of Forest Research 60(2):327-334. https://doi.org/10.15287/afr.2017.897

Guo S, Wei H, Li J, Fan R, Xu M, Chen X, Wang Z (2019). Geographical distribution and environmental correlates of Eleutherosides and Isofraxidin in Eleutherococcus senticosus from Natural populations in forests at Northeast China. Forests 10:872. https://doi.org/10.3390/f10100872

He C, Zhao Y, Zhang J, Gao J (2020). Chitosan oligosaccharide addition to Buddhist pine (Podocarpus macrophyllus (Thunb) Sweet) under drought: Responses in Ecophysiology and $\delta^{13} \mathrm{C}$ abundance. Forests 11:526. https://doi.org/10.3390/f11050526

He C, Gao J, Zhao Y, Liu J (2021). Foot foraging precision of Pinus pumila (Pall.) Regel subjected to contrasting light spectra. Plants-Basel 10(7):1482. https://doi.org/10.3390/plants10071482

IPCC (2007). Regional Climate Projections - Polar Regions. In: Fu C, Giorgi F (Eds). Climate change 2007: contribution of working group I to the fourth assessment report of the intergovern-mental panel on climate change. Cambridge University Press, Cambridge, United Kingdom. pp 902-909.

IPCC (2014). Climate change 2014: impacts, adaptation, and vulnerability. Contribution of Working Group II to the Fifth Assessment Report of the Intergovernmental Panel on Climate Change. Retrieved 2020 February 12 from https://www.ipcc.ch/report/ar5/wg2

Jia WW, Jiang SW, Li FR (2008). Biomass of single tree Pinus sylvestris var. mongolica in eastern Heilongjiang. Journal of Liaoning Forestry Science and Technology 3:5-9. (in Chinese with English abstract)

Kajimoto T (1993). Shoot dynamics of Pinus pumila in relation to altitudinal and wind exposure gradients on the Kiso Mountain range, central Japan. Tree Physiology 13:41-53. https://doi.org/10.1093/treephys/13.1.41

Li XN, Guo QX, Wang XC, Zheng HF (2010). Allometry of understory tree species in a natural secondary forest in northeast China. Scientia Silvae Sinicae 46(8):22-32. (in Chinese with English abstract)

Liu CF, Li XM (2012). Carbon storage and sequestration by urban forests in Shenyang, China. Urban Forestry \& Urban Greening 11(2):121-128, https://doi.org/10.10.1016/j.ufug.2011.03.002

Manusch C, Bugmann H, Wolf A (2014). The impact of climate change and its uncertainty on carbon storage in Switzerland. Regional Environmental Change 14:1437-1450. https://doi.org/10.1007/s10113-014-0586-Z 
Makoto K, Bryanin SV, Lisovsky VV, Kushida K, Wada N (2016). Dwarf pine invasion in an alpine tundra of discontinuous permafrost area: effects on fine root and soil carbon dynamics. Trees - Structure and Function 30(2):431-439. https://doi.org/10.1007/s00468-015-1192-5

Moskalyuk TA (2008). On adaptations of trees and shrubs in the north of the Russian Far East. Russian Journal of Ecology 39(2):73-82. https://doi.org/10.1134/S106741360802001X

Myers-Smith IH, Forbes BC, Wilmking M, Hallinger M, Lantz T, Blok D, ... Hik DS (2011). Shrub expansion in tundra ecosystems: dynamics, impacts and research priorities. Environmental Research Letter 6:045509. https://doi.org/10.1088/1748-9326/6/4/045509

Okitsu S, Ito K (1984). Vegetation dynamics of the Siberian dwarf pine (Pinus pumila Regel) in the Taisetsu mountain range, Hokkaiko, Japan. Vegetation 58(2):105-113. https://doi.org/10.1007/BF00044934

Okitsu S (1985). Consideration on vegetational zonation based on the establishment process of a Pinus pumila zone in Hokkaiko, northern Japan. Japanese Journal of Ecology 35:113-121. (in Japanese with English summary)

Okitsu S, Ito K (1989). Conditions for the development of the Pinus pumilla zone of Hokkaido, northern Japan. Vegetation 84:127-132. https://doi.org/10.1007/BF00036513

Okuda M, Sumida A, Ishii H, Vetrova VP, Hara T (2008). Establishment and growth pattern of Pinus pumila under a forest canopy in central Kamchatka. Ecological Research 23:831-840. https://doi.org/10.1007/s11284-007-0445-1

Sano Y, Matano T, Ujihara A (1977). Growth of Pinus pumila and climate fluctuation in Japan. Nature 266(5598):159161. https://doi.org/10.1038/266159aO

Takahashi K (2003). Effects of climatic conditions on shoot elongation of Alpine dwarf pine (Pinus pumila) at its upper and lower altitudinal limits in central Japan. Arctic, Antarctic and Alpine Research 35(1):1-7. https://doi.org/10.1657/1523-0430(2003)035[0001:EOCCOS]2.0.CO;2

Takahashi K, Furuhata K (2016). Shoot growth and seasonal changes of nonstructural carbohydrate concentrations at the upper and lower distribution limits of three conifers. Landscape and Ecological Engineer 12(2):239-245. https://doi.org/10.1007/s11355-016-0294-6

Takahashi K, Hirosawa T, Morishima R (2012). How the timberline formed: altitudinal changes in stand structure and dynamics around the timberline in central Japan. Annals of Botany 109:1165-1174. https://doi.org/10.1093/aob/mcs043

Takahashi K, Yoshida S (2009). How the scrub height of dwarf pine Pinus pumila decreases at the treeline. Ecological Research 24:847-854. https://doi.org/10.1007/s11284-008-0558-1

Uehara Y, Kume A, Chiwa M, Honoki H, Zhang J, Watanabe K (2015). Atmospheric deposition and interactions with Pinus pumila Regal canopy on Mount Tateyama in the Northern Japanese Alps. Arctic, Antarctic and Alpine Research 47(2):389-399. https://doi.org/10.1657/AAAR0013-126

Wang CK (2006). Biomass allometric equations for 10 co-occurring tree species in Chinese temperate forests. Forest Ecology and Management 222(1):9-16. https://doi.org/10.1016/j.foreco.2005.10.074

Wang XY, Yu DP, Wang SL, Lewis BJ, Zhou WM, Zhou L, Dai LM, Lei JP, Li MH (2017). Tree height-diameter relationships in the alpine treeline ecotone compared with those in closed forests on Changbai Mountain, Northeastern China. Forests 8:132. https://doi.org/10.3390/f8040132

Wagner B, Liang E, Li XX, Dulamsuren C, Leuschner C, Hauck M (2015). Carbon pools of semi-arid Picea crassifolia forests in the Qilian Mountains (north-eastern Tibetan Plateau). Forest Ecology and Management 343:136-143. https://doi.org/10.1016/j.foreco.2015.02.001

Wei H, Chen X, Chen G, Zhao H (2019). Foliar nutrient and carbohydrate in Aralia elata can be modified by understory light quality in forests with different structures at Northeast China. Annals of Forest Research 62(2):125-137. https://doi.org/10.15287/afr.2019.1395

Wei H, He XY (2021a). Foliar C/N stoichiometry in urban forest trees on a global scale. Journal of Forestry Research 32:1429-1443. https://doi.org/10.1007/s11676-020-01188-6

Wei H, Chen G, Chen X, Zhao H (2021b). Geographical distribution of Aralia elata characteristics correlated with topography and forest structure in Heilongiang and Jilin provinces, Northeast China. Journal of Forestry Research 32:1115-1125. http://doi.org/10.1007/s11676-020-01100-2

Wen L, Dong SK, Li YY, Wang XX, Li XY, Shi JJ, Dong QM (2013). The impact of land degradation on the C pools in alpine grasslands of the Qinghai-Tibet Plateau. Plant and Soil 368:329-340. https://doi.org/10.1007/s11104012-1500-4 
Yue TX, Wang YF, Du ZP, Zhao MW, Zhang LL, Zhao N, Lu M, Larocque GR, Wilson JP (2016). Analysing the uncertainty of estimating forest carbon stocks in China. Biogeosciences 13:3991-4004. https://doi.org/10.5194/bg-13-3991-2016

Zhang D, Zheng HF, Ren ZB, Zhai C, Shen GQ, Mao ZX, Wang PJ, He XY (2015). Effects of forest type and urbanization on carbon storage of urban forests in Changchun, Northeast China. Chinese Geographical Science 25(2):147-158. https://doi.org/10.1007/s11769-015-0743-4

Zou CM, Bu J, Xu WD (1995). Biomass and productivity of Pinus sylvestriformis plantation. Chinese Journal of Applied Ecology 6(2):123-127. (in Chinese)

OPEN ACCESS

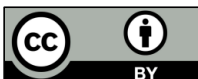

The journal offers free, immediate, and unrestricted access to peer-reviewed research and scholarly work. Users are allowed to read, download, copy, distribute, print, search, or link to the full texts of the articles, or use them for any other lawful purpose, without asking prior permission from the publisher or the author.

License - Articles published in Notulae Botanicae Horti Agrobotanici Cluj-Napoca are Open-Access, distributed under the terms and conditions of the Creative Commons Attribution (CC BY 4.0) License. (C) Articles by the authors; UASVM, Cluj-Napoca, Romania. The journal allows the author(s) to hold the copyright/to retain publishing rights without restriction. 